\title{
PENDUGAAN UMUR SIMPAN MENGGUNAKAN METODE ACCELERATED SHELF-LIFE TESTING (ASLT) DENGAN PENDEKATAN ARRHENIUS PADA DESTILAT CUKA FERMENTASI HASIL SAMPING CAIRAN PULPA KAKAO
}

\author{
I Gede Rusli Supariatna ${ }^{1}$, G. P. Ganda Putra ${ }^{2}$, Lutfi Suhendra ${ }^{2}$ \\ ${ }^{1}$ Mahasiswa Jurusan Teknologi Industri Pertanian, Fakultas Teknologi Pertanian Unud \\ ${ }^{2}$ Dosen Jurusan Teknologi Industri Pertanian, Fakultas Teknologi Pertanian Unud \\ E-mail : r.suparianta@yahoo.com \\ E-mail koresponden: gandaputra@unud.ac.id
}

\begin{abstract}
The atms of this study were (1) to knowing the change of quality characteristics from destilated fermentation vinegar from pulp liquid waste of cocoa beans during storage dan (2) to determine shelf life of destilated fermentation vinegar from pulp liquid waste of cocoa beans using Accelerated shelf-life testing (ASLT) method with Arrhenius approach. The observed Parameters is temperature. The temperature is $30{ }^{\circ} \mathrm{C}, 40{ }^{\circ} \mathrm{C}$ and $50{ }^{\circ} \mathrm{C}$. The Observed variable is acetic acid content, $\mathrm{pH}$, total dissolved solids and absorbance. The result showed that acetic acid content had the greatest decrease in $50{ }^{\circ} \mathrm{C}$ temperature. This shows that acetic acid content are inversely proportional to temperature rise. While the content of $\mathrm{pH}$, total dissolved solids and turbidity experienced the greatest increase in $50{ }^{\circ} \mathrm{C}$ temperature. This shows that $\mathrm{pH}$, total dissolved solids and turbidity are proportional to the temperature rise. The results of the calculation showed that at a temperature of $20{ }^{\circ} \mathrm{C}, 30{ }^{\circ} \mathrm{C}$, $40{ }^{\circ} \mathrm{C}$ and $50{ }^{\circ} \mathrm{C}$ has a shelf life of 226 days, 167 days, 126 days, 96 days andn 75 days.
\end{abstract}

Keywords: Destilated fermentation vinegar of cocoa, Accelerated shelf-life testing, Shelf life

\section{PENDAHULUAN}

Kakao (Theobroma cocoa L.) adalah salah satu komoditas perkebunan andalan yang banyak ditanam dan dikembangkan di berbagai wilayah di Indonesia yang berperan cukup penting bagi perekonomian nasional. Sampai dengan tahun 2016 luas area perkebunan kakao di Indonesia telah mencapai 1.722.315 Ha, dengan produksi mencapai 760.429 ton biji kakao (ditjen perkebunan, 2016). Cairan pulpa kakao mengandung asam asetat 1,6\%, etil alkohol $0,5 \%$, asam sitrat 0,5\% dan memiliki $\mathrm{pH}$ 6,5 (Case, 2004). Selama fermentasi dapat dihasilkan cairan pulpa 15-20\% dari berat biji kakao yang difermentasi (Ganda-Putra et al., 2008). Potensi cairan pulpa yang cukup besar tersebut selama ini hanya dibuang dan dianggap limbah di sekitar tempat pengolahan, selain akan mengotori juga dapat berdampak buruk atau mencemari bagi lingkungan di sekitarnya.

Penyimpanan merupakan usaha untuk mempertahankan keadaan dari sejak awal diproduksi hingga saatnya digunakan (Santoso, 2003). Faktor-faktor penting didalam penyimpanan adalah suhu, kelembaban, kualitas bahan dan komposisi atmosfir. Suhu dalam penyimpanan seharusnya dipertahankan agar tidak fluktuatif. Penentuan umur simpan produk pangan dapat dilakukan dengan cara menyimpan produk pada kondisi penyimpanan yang sebenarnya hingga produk tersebut mengalami kerusakan maksimal atau sering disebut dengan Extended Storage Studies (ESS). Pada metode Extended Storge Studies (ESS) dapat menghasilkan hasil yang tepat dan akurat, namun biasanya memerlukan waktu yang lama dan biaya yang besar. Pendugaan umur simpan pada produk juga dapat dilakukan dengan metode 
Accelerated shelf-life testing (ASLT), yaitu dengan penyimpanan produk pangan pada lingkungan yang menyebabkan terjadinya kerusakan dengan cepat, baik pada kondisi suhu atau kelembaban ruang penyimpanan yang lebih tinggi dari pada kondisi sebenarnya. Metode Accelerated shelf-life testing (ASLT) yang sering digunakan adalah model Arrhenius dan model Kadar Air Kritis (Kusnandar, 2010). Umur simpan cuka fermentasi dihitung dengan menggunakan persamaan kinetika reaksi berdasarkan orde reaksinya, jika reaksi berlangsung pada orde 0 maka ts $=\left(A_{0}-A_{t}\right) / k$, sedangkan untuk orde 1 adalah ts $=\left(\ln A_{0} / l n A_{t}\right) / k$.

Tujuan dari penelitian ini adalah 1) mengetahui perubahan karakteristik mutu destilat cuka fermentasi hasil samping cairan pulpa kakao selama penyimpanan dan 2) menentukan umur simpan destilat cuka fermentasi hasil samping cairan pulpa kakao menggunakan metode Accelerated shelf-life testing (ASLT) dengan pendekatan Arrhenius.

\section{METODE PENELITIAN}

\section{Tempat dan Waktu Penelitian}

Penelitian ini dilakukan di Laboratorium Rekayasa dan Proses Jurusan Teknologi Industri Pertanian, Laboratorium Analisis Pangan Jurusan Ilmu dan Teknologi Pangan, Fakultas Teknologi Pertanian Universitas Udayana. Penelitian ini dimulai pada bulan Agustus sampai November 2017.

\section{Alat dan Bahan}

Bahan yang diperlukan dalam penelitian ini adalah destilat cuka fermentasi pulpa biji kakao yang didapat dari produksi kakao Desa Angkah dengan persentase pengambilan volume destilat sebanyak $90 \% \mathrm{v} / \mathrm{v}$ dengan waktu fermentasi selama 120,25 menit, sedangkan bahan-bahan kimia yang digunakan diantaranya : $\mathrm{NaOH}, \mathrm{HCl}$, polipropena (pp), aquades, asam oksalat dan $\mathrm{NaCl}$.

Peralatan yang diperlukan dalam penelitian ini diantaranya : Inkubator (Mammert), timbangan analitik (Shimadzu), $\mathrm{pH}$ meter (Ditech), piknometer, labu ukur (Iwaki), spektrofotometer (Genesys 10S UV-VIS), autoclave (Hirayama), sentrifuse (Centurion Scientific), botol kaca dengan penutup plastik berkapasitas $100 \mathrm{ml}$, gunting, kertas saring, biuret, water bath, aluminium foil, tisu, lemari pendingin, batang pengaduk, magnetic stirer, dan alat-alat gelas.

\section{Rancangan Percobaan}

Penelitian ini dilakukan dengan menggunakan metode Accelerated shelf-life testing (ASLT) berdasarkan pendekatan semi empiris dengan bantuan persamaan Arrhenius, dengan teori kinetika yang pada umumnya menggunakan ordo 0 atau orde 1 untuk pangan. Penelitian ini merupakan eksperimen dengan menyimpan destilat cuka pada inkubator yang suhunya diatur untuk mempercepat penurunan mutu pada destilat cuka. Suhu yang dipakai adalah masing-masing $30^{\circ} \mathrm{C}, 40^{\circ} \mathrm{C}$ dan $50^{\circ} \mathrm{C}$.

\section{Tahapan Penelitian}

\section{Pelaksanaan Penelitian}

Penelitian ini dilakukan dengan menggunakan metode Accelerated shelf-life testing (ASLT) berdasarkan pendekatan semi empiris dengan bantuan persamaan Arrhenius. Sampel destilat cuka fermentasi hasil samping cairan pulpa kakao sebanyak $100 \mathrm{ml}$ dikemas menggunakan botol kaca dengan penutup plastik sebanyak 96 botol. Penelitian dilakukan selama 112 hari dengan cara menyimpan sampel destilat cuka fermentasi cairan pulpa kakao pada suhu $30^{\circ} \mathrm{C}, 40^{\circ} \mathrm{C}$ dan $50^{\circ} \mathrm{C}$. Pengamatan dilakukan setiap 7 hari sekali. 


\section{Penentuan Karakteristik Mutu Awal (A) dan Mutu Akhir (At) Destilat Cuka Hasil Samping Fermentasi Cairan Pulpa Kakao.}

Penentuan mutu awal $\left(\mathrm{A}_{0}\right)$ dilakukan dengan cara analisis kadar asam asetat, $\mathrm{pH}$, total padatan terlarut, dan kekeruhan. Hasil dari analisis tersebut merupakan karakteristik mutu awal $\left(\mathrm{A}_{0}\right)$. Penentuan mutu akhir $\left(\mathrm{A}_{\mathrm{t}}\right)$ dapat ditentukan dengan batasan penurunan mutu mencapai lebih dari $50 \%$ dari mutu awal $\left(\mathrm{A}_{0}\right)$ produk pada suhu kritis $\left(50{ }^{\circ} \mathrm{C}\right)$ (Sina et al,. 2004).

\section{Penentuan Laju Penurunan Mutu dan Perhitungan Umur Simpan Destilat Cuka Hasil Fermentasi Cairan Pulpa Kakao}

Data hasil analisis produk diplotkan terhadap waktu dan diperoleh persamaan regresi liniernya, kemudian diperoleh tiga persamaan regresi untuk 3 kondisi suhu penyimpanan dengan menggunakan $y=a+b x$, dimana $y=$ nilai karakteristik cuka fermentasi, $x=$ waktu penyimpanan (hari), a = nilai karakteristik mutu cuka fermentasi pada awal penyimpanan dan $\mathrm{b}=$ laju perubahan nilai karakteristik. Dari masing-masing persamaan tersebut diperoleh nilai slope (b) yang merupakan konstanta laju reaksi perubahan karakteristik produk atau laju penurunan mutu (k). Untuk menentukan orde reaksi yang digunakan dibuat grafik orde nol yaitu hubungan antara nilai k dengan lama penyimpanan dan orde satu yaitu hubungan antara ln k dengan lama penyimpanan. Dari kedua persamaan tersebut dipilih yang mempunyai nilai $\mathrm{R}^{2}$ terbesar.

Untuk pendekatan Arrhenius, nilai k diplotkan terhadap 1/T (K-1) dan ln k, didapatkan nilai intersep dan slope dari persamaan regresi linier $\ln \mathrm{k}=\ln \mathrm{k} 0-(\mathrm{E} / \mathrm{R})(1 / \mathrm{T})$. Dimana $\ln \mathrm{k} 0$ $=$ intersep, $\mathrm{E} / \mathrm{R}=$ slope, $\mathrm{Ea}=$ energi aktivasi dan $\mathrm{R}=$ kosntanta gas ideal $\left(1,986 \mathrm{kal} / \mathrm{mol} .{ }^{\circ} \mathrm{K}\right)$. Dari persamaan tahap kelima diperoleh nilai konstanta $\mathrm{k}_{0}$ yang merupakan faktor eksponensial dan niai energi aktivasi reaksi perubahan karakteristik cuka fermentasi $(\mathrm{Ea}=\mathrm{E})$. Kemudian ditentukan model persamaan laju reaksi $(\mathrm{k})$ perubahan karakteristik cuka fermentasi dengan $k=k 0 . e-E / R T$. Setelah didapatkan persamaan Arrhenius, dapat dihitung nilai konstanta Arrhenius (k) pada suhu (T) penyimpanan yang ditentukan. Penentuan parameter kunci dengan melihat parameter yang mempunyai energi aktivasi terendah.

Umur simpan cuka fermentasi dihitung dengan menggunakan persamaan kinetika reaksi berdasarkan orde reaksinya, yaitu jika reaksi berlangsung pada orde nol maka ts $=\left(\mathrm{A}_{0^{-}}\right.$ $\left.A_{t}\right) / k$, sedangkan untuk orde satu adalah ts $=\left(\ln A_{0} / A_{t}\right) / k$. Untuk penentuan umur simpan pada suhu normal adalah dengan memasukan nilai suhu (konversi ${ }^{\circ} \mathrm{C}$ menjadi $\mathrm{K}$ ) ke dalam persamaan $\ln \mathrm{k}=\ln \mathrm{k} 0-(\mathrm{E} / \mathrm{R})(1 / \mathrm{T})$ dan didapat nilai, kemudian nilai $\mathrm{k}$ dimasukkan ke dalam persamaan orde reaksi untuk mendapatkan umur simpan cuka fermentasi.

\section{Variabel yang Diamati}

Variabel yang diamati adalah kadar asam asetat (SNI 01-3711-1995), pH (Apriyanto et al., 1988), total padatan terlarut (Wartini et al., 2014) dan kekeruhan (Yanlinastuti, 2009).

\section{HASIL DAN PEMBAHASAN}

\section{Penentuan Karakteristik Mutu Awal (Ao) dan Karakteristik Mutu Akhir (At) Destilat Cuka Fermentasi Hasil Samping Cairan Pulpa Kakao}

Destilat cuka fermentasi hasil samping cairan pulpa kakao perlu diuji masing-masing variable sebelum dilakukan penelitian untuk mengetahui karakteristik mutu awal $\left(\mathrm{A}_{0}\right)$. Sedangkan untuk karakteristik mutu akhir $\left(\mathrm{A}_{\mathrm{t}}\right)$ produk dapat ditentukan apabila produk telah mengalami penurunan lebih dari $50 \%$ dari mutu awal. 
Tabel 1. Karakteristik Mutu Awal ( $\left.A_{0}\right)$ dan Karakteristik Mutu Akhir $\left(A_{t}\right)$ Destilat Cuka Fermentasi Hasil Samping Cairan Pulpa Kakao.

\begin{tabular}{lcc}
\hline \multicolumn{1}{c}{ Variabel } & $\left(\mathrm{A}_{0}\right)$ & $\left(\mathrm{A}_{\mathrm{t}}\right)$ \\
\hline Asam Asetat $(\%)$ & 1,8 & 0,83 \\
$\mathrm{pH}$ & 2,3 & 4,3 \\
TPT ${ }^{\circ}$ Brix & 0,1 & 1,9 \\
Kekeruhan & $-0,03$ & 0,039 \\
\hline
\end{tabular}

\section{Laju Penurunan Mutu Destilat Cuka Fermentasi Hasil Samping Cairan Pulpa Kakao Asam Asetat}

Laju penurunan mutu asam asetat destilat cuka fermentasi hasil samping cairan pulpa kakao yang disimpan pada 3 kondisi suhu dapat dilihat pada Gambar 2.

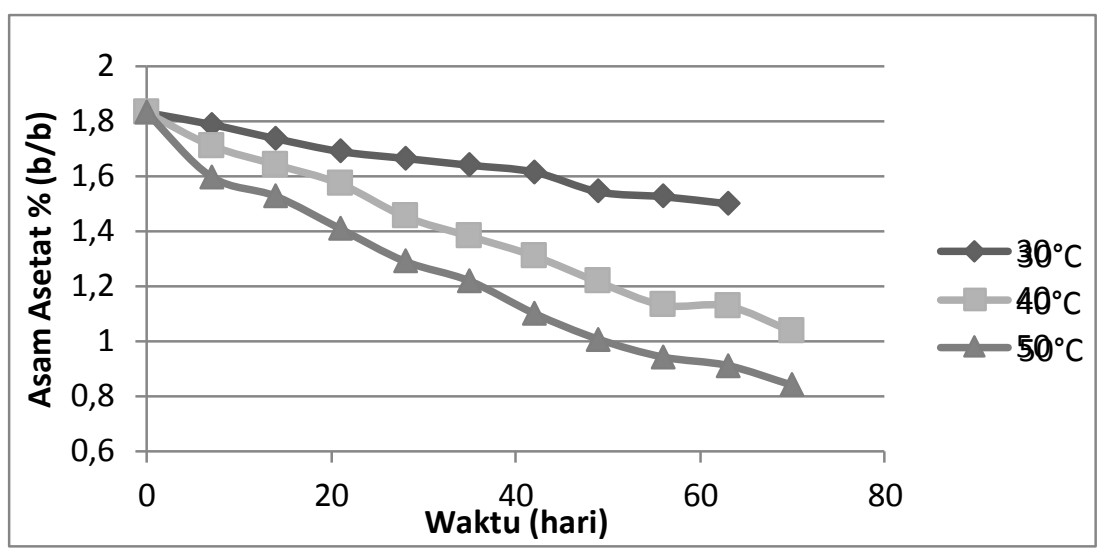

Gambar 2. Laju penurunan mutu asam asetat destilat cuka fermentasi hasil samping cairan pulpa kakao.

Penurunan nilai kadar asam asetat produk selama penyimpanan berkisar antara $1,82 \%$ $\mathrm{b} / \mathrm{b}-0,83 \% \mathrm{~b} / \mathrm{b}$. Perubahan ini terjadi karena terjadi oksidasi pada asam asetat menjadi $\mathrm{CO}_{2}$ dan $\mathrm{H}_{2} \mathrm{O}$ (Leasa dan Matdoan, 2015).

pH

Laju penurunan mutu nilai $\mathrm{pH}$ destilat cuka fermentasi hasil samping cairan pulpa kakao yang disimpan pada 3 kondisi suhu dapat dilihat pada Gambar 3.

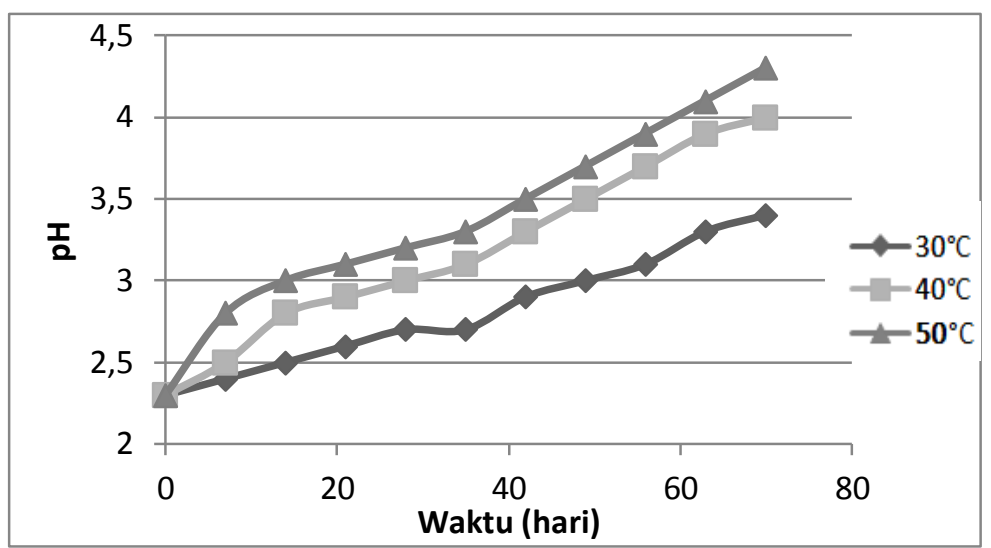

Gambar 3. Perubahan nilai pH selama penyimpanan

Perubahan nilai $\mathrm{pH}$ produk selama masa penyimpanan berkisar antara 2,3-4,3. Nilai $\mathrm{pH}$ mengalami kenaikan seiring dengan kondisi suhu dan lama penyimpanan. Hal ini dikarenakan semakin tinggi suhu dan semakin lama penyimpanan maka kadar asam asetat menjadi semakin kecil sehingga nilai $\mathrm{pH}$ mengalami kenaikan. 


\section{Total Padatan Terlarut (TPT)}

Perubahan nilai total padatan terlarut (TPT) selama penyimpanan dapat dilihat pada Gambar 4.

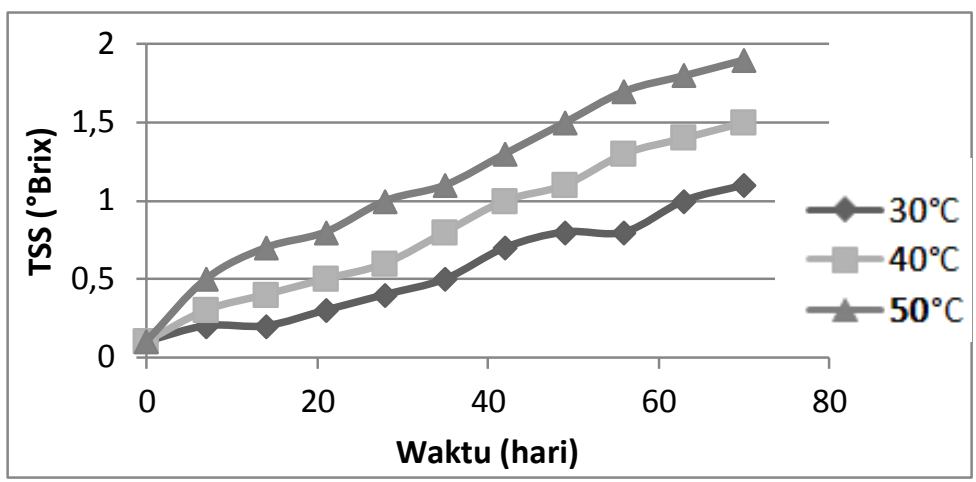

Gambar 4. Perubahan nilai total padatan terlarut (TPT) selama penyimpanan.

Perubahan nilai total padatan terlarut (TPT) produk selama masa penyimpanan berkisar antara $0,1-1,9^{\circ}$ Brix. Semakin tinggi suhu dan semakin lama penyimpanan, semakin besar peningkatan nilai total padatan terlarut (TPT).

\section{Kekeruhan}

Perubahan nilai kekeruhan selama penyimpanan produk dapat dilihat pada Gambar 5.

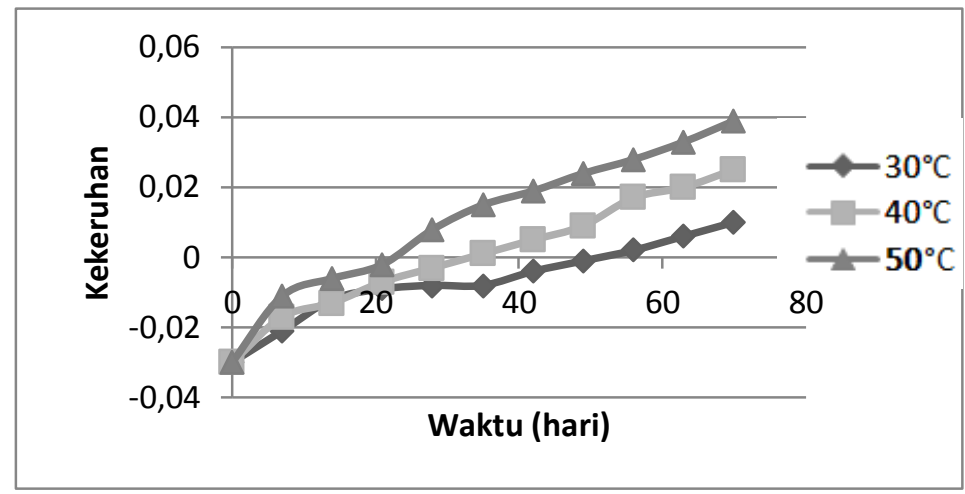

Gambar 5. Perubahan nilai kekeruhan selama penyimpanan produk.

Perubahan nilai absorbansi produk selama masa penyimpanan berkisar antara $-0,03-$ 0,039. Hal ini disebabkan karena semakin tinggi suhu dan semakin lama penyimpanan maka nilai total padatan terlarut meningkat sehingga dapat meningkatkan nilai kekeruhan. Semakin tinggi suhu penyimpanan, semakin besar nilai kekeruhan pada produk (Hecht, 1997).

\section{Penentuan Orde Reaksi}

Penentuan orde reaksi dilakukan dengan cara memplotkan masing-masing data perlakuan suhu sehingga didapatkan persamaan regresi linier baik pada orde 0 maupun pada orde 1 . Orde reaksi yang memiliki nilai koefisien $\mathrm{R}^{2}$ tertinggi akan digunakan untuk menentukan perhitungan umur simpan destilat cuka fermentasi hasil samping cairan pulpa kakao (Dewi, 2015). 


\section{Asam Asetat}

Persamaan regresi parameter kadar asam asetat pada orde 0 dan orde 1 dapat dilihat pada Gambar 6.

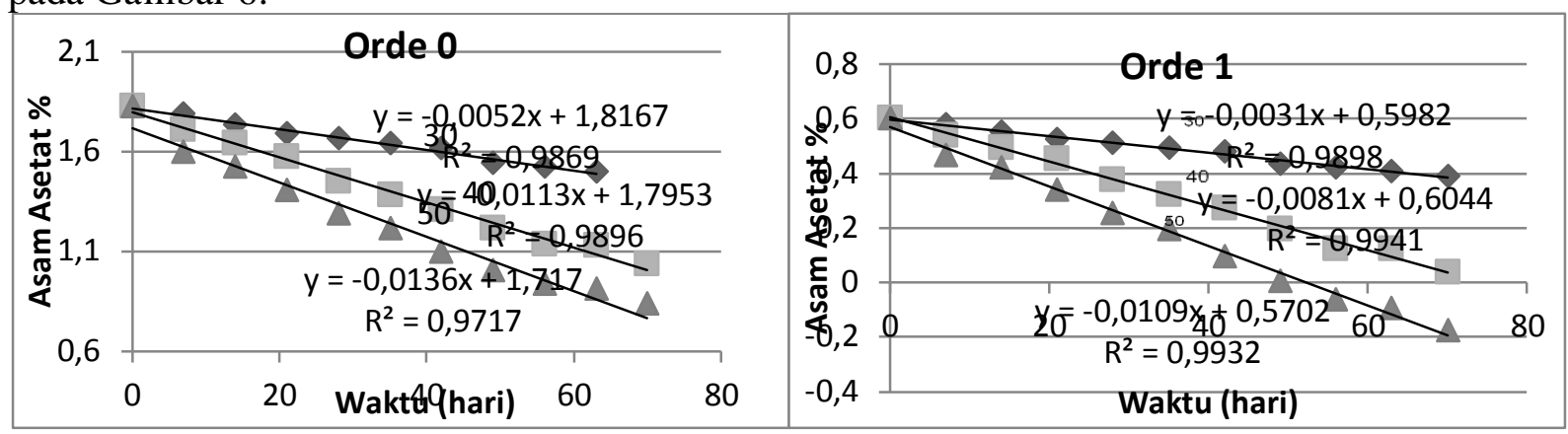

Gambar 6. Persamaan regresi parameter kadar asam asetat pada orde 0 dan orde.

Gambar 6 menunjukkan nilai koefisien $\mathrm{R}^{2}$ orde 0 pada suhu $30^{\circ} \mathrm{C}, 40^{\circ} \mathrm{C}$, dan $50^{\circ} \mathrm{C}$ berturut-turut adalah 0,986, 0,989 dan 0,971. Sedangkan pada orde 1 nilai koefisien $\mathrm{R}^{2}$ pada suhu $30^{\circ} \mathrm{C}, 40^{\circ} \mathrm{C}$, dan $50^{\circ} \mathrm{C}$ berturut-turut adalah $0,989,0,994$ dan 0,993 .

Dari diagram di atas menunjukkan nilai koefisien $\mathrm{R}^{2}$ pada orde 1 lebih besar dibandingkan nilai koefisien orde 0 . Dengan demikian, perhitungan untuk mendapatkan umur simpan destilat cuka fermentasi hasil samping cairan pulpa kakao menggunakan persamaan reaksi pada orde 1 .

pH

Persamaan regresi parameter $\mathrm{pH}$ pada orde 0 dan orde 1 dapat dilihat pada Gambar 7.

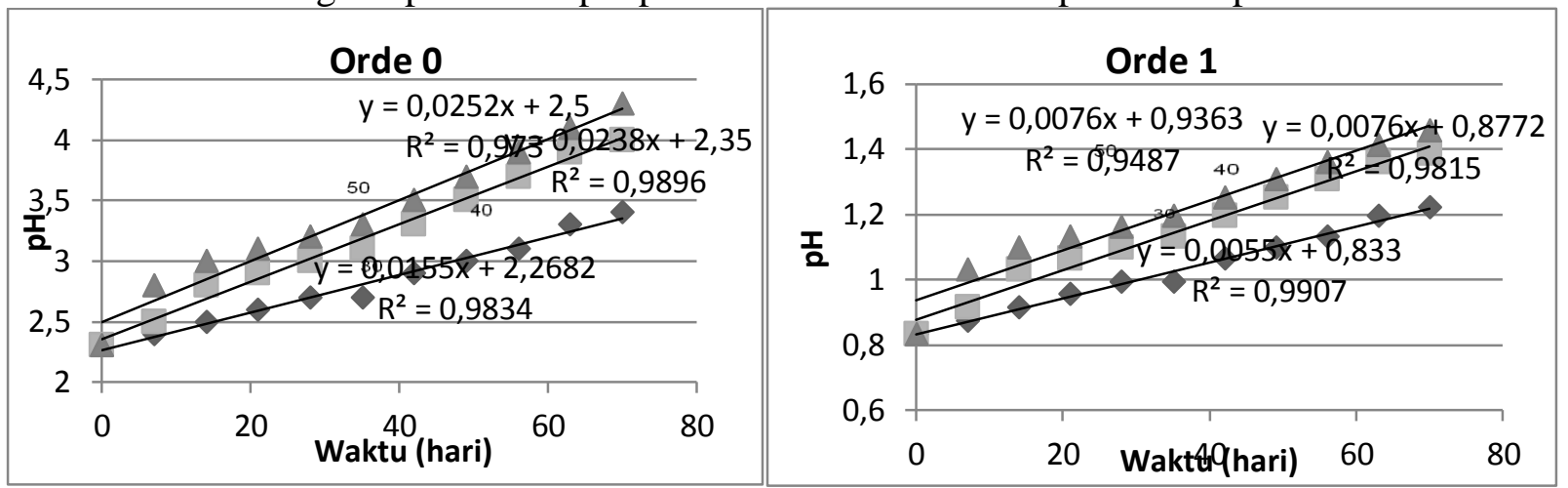

Gambar 7. Persamaan regresi parameter $\mathrm{pH}$ pada orde 0 dan orde 1.

Gambar 7 menunjukkan nilai koefisien $\mathrm{R}^{2}$ orde 0 pada suhu $30^{\circ} \mathrm{C}, 40^{\circ} \mathrm{C}$, dan $50^{\circ} \mathrm{C}$ berturut-turut adalah $0,983,0,989$ dan 0,973 . Sedangkan pada orde 1 nilai koefisien $\mathrm{R}^{2}$ pada suhu $30^{\circ} \mathrm{C}, 40^{\circ} \mathrm{C}$, dan $50^{\circ} \mathrm{C}$ berturut-turut adalah $0,990,0,981$ dan 0,948 .

Diagram di atas menunjukkan nilai koefisien $\mathrm{R}^{2}$ pada orde 0 lebih besar dibandingkan nilai koefisien orde 1 . Dengan demikian, perhitungan untuk mendapatkan umur simpan destilat cuka fermentasi hasil samping cairan pulpa kakao menggunakan persamaan reaksi pada orde 0 .

\section{Total Padatan Terlarut (TPT)}

Persamaan regresi parameter total padatan terlarut (TPT) pada orde 0 dan orde 1 dapat dilihat pada Gambar 8. 


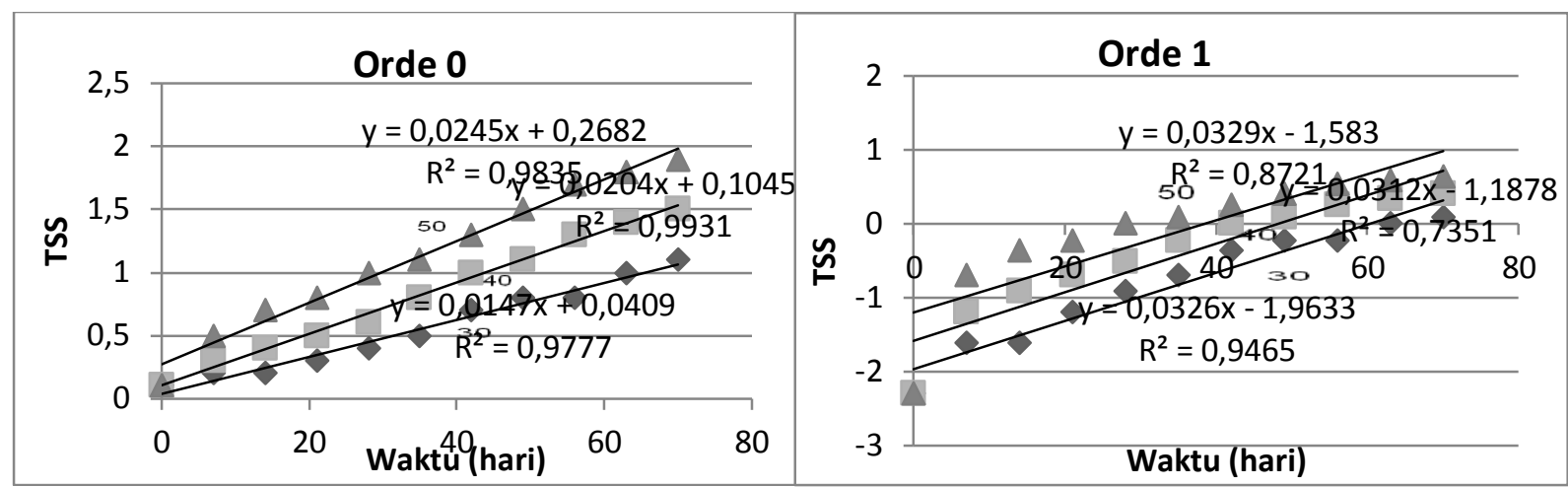

Gambar 8. Persamaan regresi parameter total padatan terlarut (TPT) pada orde 0 dan orde 1.

Gambar 8 menunjukkan nilai koefisien $\mathrm{R}^{2}$ orde 0 pada suhu $30^{\circ} \mathrm{C}, 40^{\circ} \mathrm{C}$, dan $50^{\circ} \mathrm{C}$ berturut-turut adalah $0,977,0,993$ dan 0,983 . Sedangkan pada orde 1 nilai koefisien $\mathrm{R}^{2}$ pada suhu $30^{\circ} \mathrm{C}, 40^{\circ} \mathrm{C}$, dan $50^{\circ} \mathrm{C}$ berturut-turut adalah $0,946,0,735$ dan 0,872 . Rekapan persamaan regresi parameter kadar asam asetat dapat dilihat pada Tabel 4.

Diagram di atas menunjukkan nilai koefisien $\mathrm{R}^{2}$ pada orde 0 lebih besar dibandingkan nilai koefisien orde 1, sehingga perhitungan untuk mendapatkan umur simpan destilat cuka fermentasi hasil samping cairan pulpa kakao menggunakan persamaan reaksi pada orde 0 .

\section{Kekeruhan}

Persamaan regresi parameter Kekeruhan pada orde 0 dan orde 1 dapat dilihat pada Gambar 9.

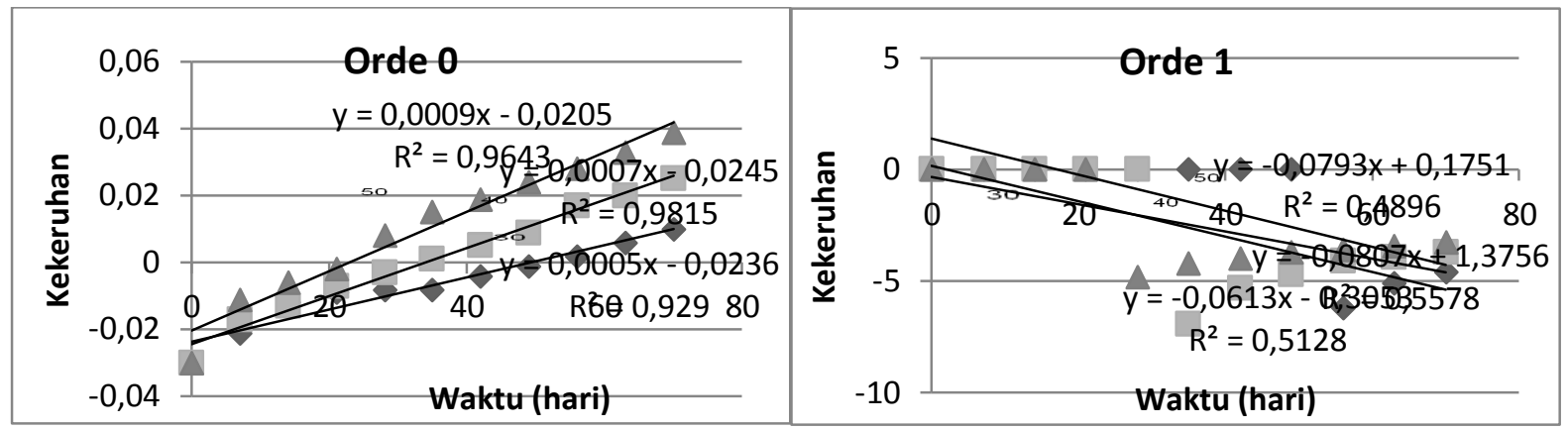

Gambar 9. Persamaan regresi parameter kekeruhan pada orde 0 dan orde 1.

Gambar 9 menunjukkan nilai koefisien $\mathrm{R}^{2}$ orde 0 pada suhu $30^{\circ} \mathrm{C}, 40^{\circ} \mathrm{C}$, dan $50^{\circ} \mathrm{C}$ berturut-turut adalah $0,929,0,981$ dan 0,964 . Sedangkan pada orde 1 nilai koefisien $\mathrm{R}^{2}$ pada suhu $30^{\circ} \mathrm{C}, 40^{\circ} \mathrm{C}$, dan $50^{\circ} \mathrm{C}$ berturut-turut adalah $0,557,0,512$ dan 0,489 .

Tabel 5 menunjukkan nilai koefisien $\mathrm{R}^{2}$ pada orde 0 lebih besar dibandingkan nilai koefisien orde 1 , sehingga perhitungan untuk mendapatkan umur simpan destilat cuka fermentasi hasil samping cairan pulpa kakao menggunakan persamaan reaksi pada orde 0 .

\section{Persamaan Arrhenius}

Persamaan Arrhenius didapatkan dengan cara memplotkan ln k dan 1/T sehingga akan didapatkan persamaan regresi dari masing-masing perlakuan. Persamaan regresi yang didapat akan digunakan untuk menghitung umur simpan destilat cuka fermentasi hasil samping cairan pulpa kakao.

\section{Asam Asetat}

Grafik regresi linier antara ln $\mathrm{k}$ dan 1/T pada parameter kadar asam asetat dapat dilihat pada Gambar 10. 


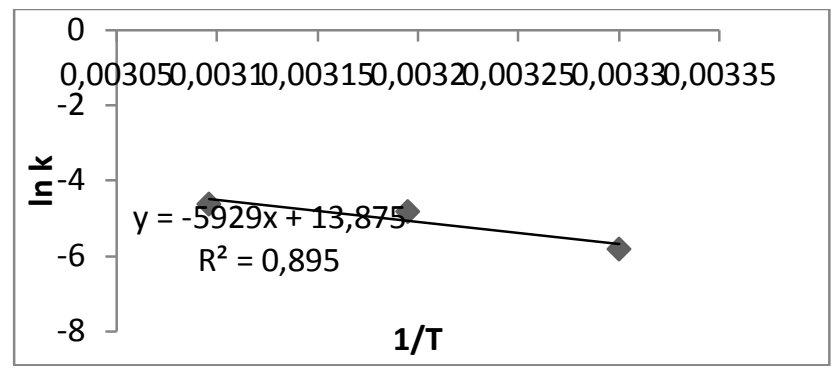

Gambar 10. Regresi linier antara $\ln \mathrm{k}$ dan $1 / \mathrm{T}$ pada parameter kadar asam asetat.

Gambar 10 menunjukkan regresi linier antara ln k dan 1/T pada parameter kadar asam asetat adalah $\mathrm{y}=-5929, \mathrm{x}+13,87$ dengan $\mathrm{R}^{2}=0,895$. Energi aktivasi (Ea) sebesar 11774,994 $\mathrm{kal} / \mathrm{mol}$ yang artinya untuk memulai terjadinya perubahan asam asetat diperlukan energi sebesar tersebut.

pH

Grafik regresi linier antara ln $\mathrm{k}$ dan $1 / \mathrm{T}$ pada parameter kadar asam asetat dapat dilihat pada Gambar 11.

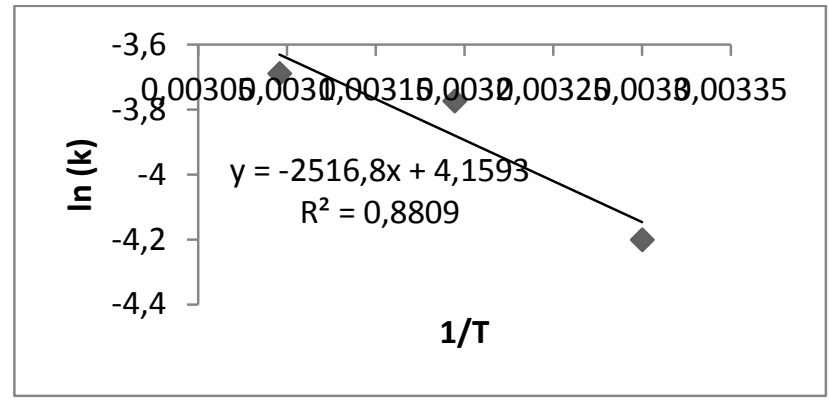

Gambar 11. Persamaan regresi linier $\ln \mathrm{k}$ dan $1 / \mathrm{T}$ pada parameter nilai $\mathrm{pH}$

Gambar 11 menunjukkan regresi linier antara $\ln \mathrm{k}$ dan $1 / \mathrm{T}$ pada parameter nilai $\mathrm{pH}$ adalah $\mathrm{y}=-2516, \mathrm{x}+4,159$ dengan $\mathrm{R}^{2}=0,880$. Energi aktivasi $(\mathrm{Ea})$ sebesar 4996,78 kal $/ \mathrm{mol}$ yang artinya untuk memulai terjadinya perubahan nilai $\mathrm{pH}$ diperlukan energi sebesar tersebut.

\section{Total Padatan Terlarut (TPT)}

Grafik regresi linier antara ln $\mathrm{k}$ dan $1 / \mathrm{T}$ pada parameter kadar asam asetat dapat dilihat pada Gambar 12.

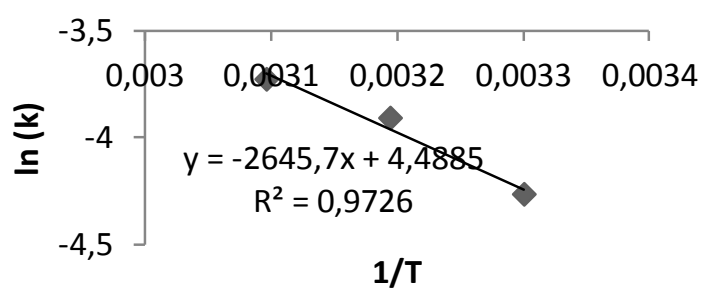

Gambar 12. Persamaan regresi linier $\ln \mathrm{k}$ dan $1 / \mathrm{T}$ pada parameter total padatan terlarut (TPT)

Gambar 12 menunjukkan regresi linier antara $\ln \mathrm{k}$ dan 1/T pada parameter total padatan terlarut (TPT) adalah $\mathrm{y}=-2645, \mathrm{x}+4,488$ dengan $\mathrm{R}^{2}=0,972$. Energi aktivasi (Ea) sebesar $5252,97 \mathrm{kal} / \mathrm{mol}$ yang artinya untuk memulai terjadinya perubahan total padatan terlarut (TPT) diperlukan energi sebesar tersebut. 


\section{Kekeruhan}

Grafik regresi linier antara $\ln \mathrm{k}$ dan $1 / \mathrm{T}$ pada parameter kadar asam asetat dapat dilihat pada Gambar 13.

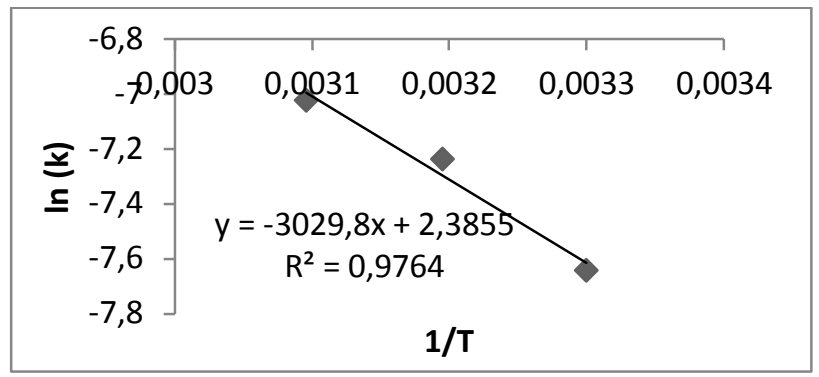

Gambar 13. Persamaan regresi linier ln $\mathrm{k}$ dan $1 / \mathrm{T}$ pada parameter kekeruhan

Gambar 13 menunjukkan regresi linier antara ln $\mathrm{k}$ dan 1/T pada parameter kekeruhan adalah $\mathrm{y}=-3029, \mathrm{x}+2,385$ dengan $\mathrm{R}^{2}=0,976$. Energi aktivasi $(\mathrm{Ea})$ sebesar $6015,594 \mathrm{kal} / \mathrm{mol}$ yang artinya untuk memulai terjadinya perubahan kedar kekeruhan diperlukan energi sebesar tersebut.

\section{Penentuan Parameter Kritis}

Menurut Kusnandar (2010) Parameter kritis pendugaan umur simpan destilat cuka fermentasi hasil samping cairan pulpa kakao dipilih berdasarkan parameter yang memiliki Energi Aktivasi (Ea) terendah. Persamaan regresi linier dan energi aktivasi (Ea) untuk setiap parameter destilat cuka fermentasi hasil samping cairan pulpa kakao dapat dilihat pada Tabel 6.

Tabel 6. Persamaan Regresi Linier dan Energi Aktivasi (Ea) untuk Setiap Parameter Destilat Cuka Fermentasi Hasil Samping Cairan Pulpa Kakao.

\begin{tabular}{lcc}
\hline \multicolumn{1}{c}{ Parameter } & Persamaan Linier & Energi Aktivasi \\
\hline Asam Asetat & $\mathrm{y}=-5929 \mathrm{x}+13,87$ & 11774,994 \\
Ph & $\mathrm{y}=-2516, \mathrm{x}+4,159$ & 4996,776 \\
TPT & $\mathrm{y}=-2645, \mathrm{x}+4,488$ & 5252,97 \\
Kekeruhan & $\mathrm{y}=-3029, \mathrm{x}+2,385$ & 6015,594 \\
\hline
\end{tabular}

Tabel 6 menunjukkan parameter yang dapat digunakan sebagai parameter kritis dari destilat cuka frmentasi hasil samping cairan pulpa kakao adalah parameter $\mathrm{pH}$. Persamaan linier untuk parameter $\mathrm{pH}$ adalah $\mathrm{y}=-2516, \mathrm{x}+4,159$ dengan Energi Aktivasi (Ea) sebesar $4996,776 \mathrm{kal} / \mathrm{mol}$ dan memiliki $\mathrm{R}^{2}$ sebesar 0,880 .

\section{Pendugaan Umur Simpan Destilat Cuka Fermentasi Hasil Samping Cairan Pulpa Kakao}

Pendugaan umur simpan destilat cuka fermentasi hasil samping cairan pulpa kakao dihitung menggunakan persamaan regresi linier berdasarkan parameter kritis yang terpilih. Berdasarkan hasil perhitungan telah didapatkan parameter kritis untuk penentuan umur simpan destilat cuka fermentasi hasil samping cairan pulpa kakao berada pada parameter $\mathrm{pH}$ dengan orde reaksi ke-0. Umur simpan destilat cuka fermentasi hasil samping cairan pulpa kakao dapat dilihat pada Tabel 7. 
Tabel 7. Umur Simpan Destilat Cuka Fermentasi Hasil Samping Cairan Pulpa Kakao.

\begin{tabular}{ccccc}
\hline \multirow{2}{*}{ Suhu } & \multirow{2}{*}{ Nilai k } & \multicolumn{3}{c}{ Umur Simpan } \\
\cline { 3 - 5 } & & Hari & Minggu & Bulan \\
\hline 10 & 0,00881 & 226 & 32,4 & 8,1 \\
20 & 0,01194 & 167 & 23,9 & 5,9 \\
30 & 0,01585 & 126 & 18,02 & 4,5 \\
40 & 0,02066 & 96 & 13,8 & 3,4 \\
50 & 0,0265 & 75 & 10,7 & 2,6 \\
\hline
\end{tabular}

Tabel 7 menunjukkan bahwa semakin tinggi suhu penyimpanan maka umur simpan destilat cuka fermentasi hasil samping cairan pulpa kakao semakin cepat mengalami kerusakan. Umur simpan destilat cuka fermentasi hasil samping cairan pulpa kakao pada suhu $10{ }^{\circ} \mathrm{C}, 20{ }^{\circ} \mathrm{C}, 30{ }^{\circ} \mathrm{C}, 40{ }^{\circ} \mathrm{C}$ dan $50{ }^{\circ} \mathrm{C}$ berturut-turut adalah 226 hari $(8,1$ bulan), 167 hari (5,9 bulan), 126 hari (4,5 bulan), 96 hari (3,4 bulan) dan 75 hari (2,6 bulan).

\section{KESIMPULAN DAN SARAN}

\section{Kesimpulan}

1. Penurunan mutu destilat cuka fermentasi hasil samping cairan pulpa kakao pada berbagai perlakuan suhu penyimpanan, mengalami penurunan pada variabel kadar asam asetat. Pada variabel $\mathrm{pH}$, total padatan terlarut dan kekeruhan mengalami peningkatan. Penurunan mutu destilat cuka fermentasi hasil samping cairan pulpa kakao mengalami kerusakan paling cepat pada suhu $50{ }^{\circ} \mathrm{C}$ selama 70 hari. Kadar asam asetat mengalami penurunan dari $1,82 \% \mathrm{~b} / \mathrm{b}$ menjadi $0,83 \% \mathrm{~b} / \mathrm{b}$, nilai $\mathrm{pH}$ mengalami kenaikan dari 2,3 menjadi 4,3 pada. Nilai total padatan terlarut (TPT) mengalami kenaikan dari $0,1^{\circ}$ Brix menjadi $1,9^{\circ}$ Brix dan nilai Kekeruhan mengalami kenaikan dari -0,03 menjadi 0,039.

2. Hasil pendugaan umur simpan destilat cuka fermentasi hasil samping cairan pulpa kakao menggunakan parameter mutu kritis nilai $\mathrm{pH}$ pada suhu $10^{\circ} \mathrm{C}, 20^{\circ} \mathrm{C}, 30^{\circ} \mathrm{C}, 40^{\circ} \mathrm{C}$ dan $50^{\circ} \mathrm{C}$ berturut-turut adalah 226 hari ( 8,1 bulan), 167 hari $(5,9$ bulan), 126 hari $(4,5$ bulan), 96 hari (3,4 bulan) dan 75 hari (2,6 bulan).

\section{Saran}

Pelaku industri destilat cuka fermentasi hasil samping cairan pulpa kakao dapat menetukan umur simpan degan menekankan pada perubahan nilai $\mathrm{pH}$ sebagai parameter mutu kritis, sehingga pelaku industri tidak perlu mengamati perubahan mutu destilat cuka fermentasi hasil samping cairan pulpa kakao sampai produk mengalami kerusakan.

\section{DAFTAR PUSTAKA}

Apriyantono, A., D. Fardiaz, N.L.P. Pitasari, S. Yasni dan S. Budiyanto. 1988. Penuntun Praktek Analisis Pangan. Pusat Antar Universitas Pangan dan Gizi. Institut Pertanian Bogor. Bogor.

Direktorat Jenderal Perkebunan. 2015. Statistik Perkebunan Indonesia 2014-2016: Komoditas Kakao. Direktorat Jenderal Perkebunan, Jakarta.

Ganda-Putra, G.P., Harijiono, S. Kumalaningsih dan Aulani'am. 2008. Optimasi Kondisi Depolimerisasi Plup Biji Kakao oleh Enzim Poligalakturonase Endojinus. Jurnal Teknik Industri. 9 (1):24-34

Kusnandar, F. 2010. Kimia Pangan. Komponen Pangan. PT. Dian Rakyat. Jakarta.

Leasa, H. dan Matdoan, M. N. 2015. Pengaruh Lama Fermentasi Terhadap Total Asam Cuka Aren (Arenga pinnata Merr.). Biopendix. 1(2): 135-140. 
Santoso. B. 2003. Penyimpanan Komoditi Hortikultura. Jurnal Teknologi Dan Industri Pertanian Indonesia. 7(1): 7-11.

SNI 01-3711-1995. Standar Nasional Indonesia (SNI) Cuka Makan. Badan Standardisasi Nasional (BSN), Jakarta.

Sina, M. I., dan S. Yuwono. 2004. Pendugaan Umur Simpan Cuka Apen Menggunakan Metode Accelerated Self-Life Testing dengan Pendekatan Arrhenius. Universitas Brawijaya. Malang. 